\title{
THE CHURCH AS NATION STATE: A NEW LOOK AT ULTRAMONTANE CATHOLICISM (1850-1900)
}

\author{
Peter Rafdts \\ Nijmegen
}

\section{Secularisation and continuity}

One of the reasons that the secularisation thesis has been so immensely successful may well have becn that its dire predictions for the future of religion in modern society have been shared by most members of the Roman-Catholic hierarchy in the past two centuries.' From the Popes downward most Catholic leaders from 1800 on wcre convinced that the spread of liberty, the rise of industrial towns and the end of rural society were a threat to the survival of the Church. In thcir view the Church had reached the pinnacle of its power and influence a long time ago, in the days of Innocent III (1198-1215), when Church and state, reason and faith, freedom and obedience were happily united under the firm leadership of the Roman Pontiff. From then on it had been downhill all the way. Theological nominalism in the later Middle $\Lambda$ ges had shattered the synthesis of faith and reason, the Reformation had ruined the authority of the Papacy, the Revolution in France was a frontal attack against Christianity as such, whcreas at the same time the industrial revolution meant the end of the ordercd hierarchical society without which religion was deemed to be impossiblc.

The most famous formulation of that profound pessimism was perhaps the Syllabus Errorum, issucd by Pope Pius IX in 1864, in which the Pope in no uncertain terms repudiated any possibility of reconciliation between the Church and progress. Subsequent events such as the fall of the Papal State in 1870, the Kulturkampf in Germany, the separation of Church and state in France in 1905, the dissolution of the Habsburg Empire in 1918, and the Soviet conquest of

Two excellent recent surveys of the development of the secularisation thesis in H. McLeod, Secularisation in Westem Europe 1848-1914 (London, 2000), pp. 4-12, and Callum (. . Brown, The Death of Christian Britain. Linderstanding Secularisation 1800-2000 (London, 2001), pp. 10-14. 
Catholic Eastern Europe after 1945 all seemed to confirm the Popc's diagnosis that Catholicism had no answer to the challenges of modernity and could only really survive in untouched rural pockets in Western Ireland or Southern Portugal. In this connection it should be noted that the many apparitions of the Virgin in the nineteenth and twentieth centuries, that did so much to foster an intense new devotion among Catholics, all occurred in these rural backwaters, and also that Mary showed a definite preference for illiterate, usually female, peasants as her messengers. ${ }^{2}$ The Catholic authorities did not need Max Weber to tell them that religion was incompatible with modernity, they had reached that conclusion long before him and their only hope was that the sufferings of the present time were not worth comparing to the glory to be revealed (cf. Rom. $8,18)$. The story of the Catholic Church in the past two ccnturies has been told, therefore, in terms of suffering and persccution, as that of the last stand of a dwindling minority of believers fighting off the irresistible rise of paganism. Bccause this story tied in so well with the dominant sociological diagnosis of the place of religion in modern society, most historians have taken the popes, the bishops, and the sociologists at their word and described the history of the Catholic Church since the French Revolution in terms of regression, entrenchment, and eventual disappearance. It will be my contention that these historians were wrong, that, in fact, the Catholic Church was remarkably successful in overcoming the blows of the French and industrial revolutions, that it adapted itself quite quickly to the demands of a new socicty and that in the years between 1850 and 1960 it influenced the lives of more people more deeply than ever before in its existence.

But when trying to give some guidelines on how to rewrite the history of Roman Catholicism in the past two centuries it is not enough to be aware of the failure of the concept of secularisation. There is another storyline, still prevalent among Catholics that has to come under close scrutiny: the myth of the unique historical continuity of the Catholic Church. When nineteenth-century Catholics compared their own Church with other Christian churches, they

\footnotetext{
2 A. Dahlberg, 'The body as a principle of holism. 'Three pilgrimages to Lourdes', in Contesting the Sacred. The Anthropology of Christian Pilgrimage, eds. J. Eade and M.J. Sallnow (London, 1991), p. 31. See also Ruth Harris, Lourdes. Geschiedenis van een religieus fenomeen (Amsterdam, 1999), pp. 107-22.
} 
usually observed - in all humility, of course - that whereas other churches had been founded by humans such as Luther, Calvin or Henry VIII, the Roman Catholic Church had been founded by the divine Saviour himself, and had continued unchanged and true to its Founder in a long line of succession stretching from the apostles to the present. This unchanging continuity was supremely symbolised by the unbroken lineage of the successors of St. Peter and Vicars of Christ, the Popes. The Papacy was, and still is 10 many Catholics, the best proof that the Catholic Church is uniquely unchangeable and immovable, that it is, in fact, almost beyond history, perhaps now even more so than a hundred years ago, because the Papacy is, now that the last emperors have gone, the only institution left that has its roots in the ancient world. Catholic historiography has fully supported that view by emphasising those institutions and traditions that survived or seemed to survive the centuries and concealing from view the many changes and discontinuities that any institution must of necessity go through in order to survive. Even critics of the Church often accept that self-image without asking questions. To take one example: when discussing what happened after the Second Vatican Council many historians spoke of the end of Constantinian era or the fall of the Tridentine Church. But whatever happened to the Catholic Church in the 1960s it had nothing whatsoever to do neither with the emperor Constantine nor with the Council of Trent. Constantine's Church did not survive the fall of the Roman Empire in the West, and the Church of Trent perished ingloriously in the crisis of the French revolution. The Catholic Church that collapsed in the nineteen sixties was a product of the nineteenth century, of the era that, characteristically, was named Restoration, but was in, fact, one of thoroughgoing modernisation.

\section{Post-revolutionary chances and challenges}

The Catholic Church in the nineteenth century faced two major challenges: the disengagement of Church and state and the rise of nationalism. ${ }^{3}$ The first challenge proved manageable quite early on. The French Concordat of 1801, although abused by the clergy at the time as a defeat for the ancient rights of the Church, was in

${ }^{3}$ R. Rémond, Religion and Society in Modem Europe (Oxford, 1999), pp. 107-108. 
fact a good example of how to deal with states that for some reason or other no longer recognised Catholicism as their only and/or state religion. ${ }^{4}$ It became the model for similar treatises with Bavaria, Prussia, Austria and even Russia. Everywhere the Holy See had to agree to the immense loss of Church property that had occurred in the course of the Revolution and of the many privileges the Church had enjoyed for centuries. But on the other hand, after a while even the Roman Curia had to admit that with the loss of privileged status it had also got rid of the meddlesome interference of Catholic monarchs, who before the revolution had always been trying to make their own state churches as independent from Rome as possible. Everyone in Rome remembered vividly how it was the concerted action of the Catholic princes that in 1773 forced the Pope to dissolve his staunchest defenders, the order of the Jesuits, after it had already been dissolved in France in 1764. Also remembered was the humiliation of Pope Pius VI who, in 1782, took the extraordinary step of travelling all the way to Vienna to beg the emperor Joseph II to desist from reforming the Austrian Church without so much as even consulting the Pope. His mission was a complete failure; the emperor remained "courteously unyielding". "Although in the nineteenth century the relations between Church and states were often very difficult, a subject to which I shall return later, such high-handed interference of states in the life of the Church began to disappear with the increasing separation between the two and once the Church had got used to its new status even the most conservative prelates began to see its distinct advantages, not the least of which was the much increased power of the Holy See within the Church, in the eyes of most nineteenth-century Catholics, definitely a good thing. ${ }^{6}$

The rise of nationalism posed a far greater threat to the existence and the influence of the Catholic Church than separation of Church and state. It is now accepted by all historians that nations and nation states are not 'universal and perennial' historical phenomena but that

${ }^{4}$ Jacques Le Goff and René Rémond, eds., Histoire de la France religieuse, 4 vols. (Paris, 1988-92), 3: Du roi Très Chrétien à la laïité républicaine, 111-15.

'O. Chadwick, The Popes and European Revolution (Oxford, 1981), p. 418; for the dissolution of the Jesuits sec pp. 345-90.

6 The last example of direct interference by a Catholic prince in the election of a pope was during the conclave of 1903, when the emperor Francis Joseph of Austria, through the Bishop of Krakow, cardinal Puszyna, vetoed the election of the then Secretary of Statc, cardinal Rampolla, to the Papacy. 
to a large extent they were formed in the nineteenth century. ${ }^{j}$ The construction of nation states was an answer to the combined challenges of industrial society and the transport revolution that brought people who, for centuries, had lived in separate, local communities with their own religion, customs and language, much closer together and forced them to find a new cultural and political unity that transcended the local. ${ }^{8}$ The national state was the outcome of that process. Its success was so phenomenal and, indeed, universal, that states that did not succeed in transforming themselves into nations, such as Austria-Hungary and the Ottoman Empire, did not survive. The late twentieth century saw a new upsurge of national feeling that resulted in the collapse of the two last multicultural empires in Europe, the Soviet-Union and Yugoslavia.

There is something very peculiar to nationalism that makes it very different from political ideologies, such as liberalism and socialism. National feeling had, and still has, strong religious features, it appeals to people not just as political beings or consumers, but in their totality. It inspires love and self-sacrifice. We have become used to it, but if you think about it there is something odd about the fact that millions and millions of young men in the two last centuries were prepared to die for their fatherland as a matter of course. ${ }^{9}$ Up till the French Revolution war had been always been left to professionals. Ordinary citizens were not activcly involvcd. Dying was a professional risk that was seldom talked about, let alone glamorised. All that changed with the first levée en masse in France in 1794, when for the first time all patriotic Frenchmen were called up to defend the endangered nation. ${ }^{10}$ From then on war became the ultimate test of loyalty to the nation. It was talked about in religious terms: dying on the battlefield was a sacrifice on the altar of the fatherland and the dead were presented as martyrs in a holy cause. It is that astonishing ability to mobilisc pcoplc totally that distinguishcs nationalism from all political philosophies of the last two centuries. Even communism, with all its claims to make sense of all aspects of life, was

${ }^{7}$ E.A. Gellner, Nationalism (London, 1997), p. 7.

${ }^{8}$ For France this process is brilliantly described by E. Weber, Peasants into Frenchmen: The Modernization of Rural France 1870-1914 (London, 1979).

${ }^{9}$ Benedict Anderson, Imagined Communities: Reflections on the Origin and Spread of Nationalism, 2nd ed. (London, 1991), pp. 141-44.

${ }_{10}$ N.C.F. van Sas, Talen van het vaderland. Oter patriottisme en nationalisme (Amsterdam, 1996), pp. 10-11. 
never able to move so many people so completely. In 1941 Stalin had to present the war against Germany as a defence of Holy Russia before he got the Russians moving.

It is obvious that the strong religious feelings evoked by the nation were a threat to all churches. In the worst case it could make them superfluous, because it was now the state that could take care of all the needs that had been the domain of organised religion in previous centuries. And it certainly is true that in certain circles of the enlightened liberal bourgeoisic nationalism did, indeed, take the place that religion had had there beforc. But such secular devotion to the nation remained exceptional. On the whole the churches dealt with the challenge of nationalism quite successfully by writing themselves into the script. For most protestant and Orthodox churches that was made easier by the fact that they had a long tradition of being state churches that had always recognised the prince as the head of their organisation. It was not too difficult for them to make the change and present themselves as the church of the people, the organisation that cmbodied the noblest aspirations of the nation. And the existence of a national church also proved that the nation was the assembly of God's elect, that had a mission to all the world. England and Russia are perfect examples of such a successful transformation of the state church into a national church. The Church of England not only justified the building of the British Empire as a religious duty, it also, by presenting itself as the comprehensive church of the middle (the via media), emphasiscd the essentially benevolent and moderate nature of British political rulc." In Russia the Orthodox Church with its traditional emphasis on ritual and mysticism and its distinct lack of learning came to be seen as the perfect expression of the simple, strong, but obedient Russian peasant soul. ${ }^{12}$ But in Holland, too, many Protestants tried to reinterpret Calvinism as the religious expression of the tolerance and love of liberty that had always characterised the Dutch from the moment they abjured Catholicism and the rule of the King of Spain. ${ }^{13}$

For the Roman Catholic Church it was not so easy to come to terms with the nation state. All Christian churches taught, of course,

\footnotetext{
11 Mcleod, Secularisation (see above, n. 1), pp. 235-37.

12 Rémond, Religion and Society (see above, n. 3), pp. 85, 87, and 110.

1:3 Peter van Rooden, Religieuze regimes. Over godsdienst en maatschappij in Nederland, 1570-1990 (Amsterdam, 1996), pp. 147-68.
} 
that Christianity was universal and that its message had to be preached to all nations. But only the Roman Catholic Church made that potential universality of the Christian faith visible in its organisation, most of all in the person of the Pope. To all Catholics the Papacy represcnted the truth that in the end only God had power over all peoples and nations on earth. Even though it is true that the Pope had very little actual power in the Church before 1850, his mere prescnce in Rome had been, since the eleventh century, a testimony to the fact that first there was an authority higher than that of the king, the state and the nation, namely the authority of God and secondly that no state could claim to represent that authority, but only the Vicar of Christ, the Pope. In the heroic struggle of Pope Pius VII against the tyrant Napolcon nineteenth-century Catholics had seen a shining example of moral force and of what happened to a prince who transgresscd the limits set by God and the Church. Pius' victory and Napolcon's fall reassurcd Catholics, if they needed it, that no state could ever have the last word on anything but remained subject to the law of God. That was an unpalatable truth for the new nation states and made them decply suspicious of their Catholic subjects, a suspicion that deepened when in 1870, during the First Vatican Council, the Pope was pronounced to be infallible in matters of faith and morals.

In non-Catholic countries Catholics were accused of serving two masters, their own state and the priest-king ultra montes. In recently united Germany it came to a Kulturkampf during which the government actively tried to separate the Catholics from the authority of Rome and the Pope. ${ }^{1+}$ In Ireland and Poland the Church became the focus of opposition against the efforts of the state authorities to destroy local culture and to enforce Anglicisation or Russification. ${ }^{15}$ But in Catholic countries, too, national aspirations came into collision with the Church. The problem there was that traditionally the Church had been the most powerful institution in the land owning vast amounts of property and controlling most of education and charity. Resentment against the power of the Church and its clergy had

\footnotetext{
It Kurt Nowak, Geschichte des Christentums in Deutschland (München, 1995), pp. 149-58.

${ }^{15}$ For Poland see Norman Davies, God's Playground. A Ilistory of Poland, 2 vols. (Oxford, 1983-85), 2: 222-23; for Ireland: J. Hutchinson, The dynamics of Cultural Nationalism: The Gaelic Revival and the Creation of the Irish Nation State (London, 1987), pp. 103, 114, 136-37, 233-34, and 287-88.
} 
been rampant for more than a century in countries, such as Italy, France and Spain. That hostility translated itself in the nineteenth century into a liberal, national ideology that was consciously anticlerical. The Church was excluded from the discourse of nation, and defined not as a part of the nation's inheritance but as a competitor for the hearts of the people. In France this caused a split in national consciousness that was not healed until the $1980 \mathrm{~s}^{16}$ To be fair, there were efforts in Catholic countries to include Catholicism in a nationalist ideology, such as falangism in Spain and in France the Action française. ${ }^{17}$ But strangely enough the Roman authorities opposed these movements, although reluctantly, because they felt that Catholicism transcended everything and thus could not be part of something else. $\Lambda$ nd it was the Pope who symbolized that nations were subject to God and the Church, and not the other way round.

\section{Modernisation in the guise of restoration}

But the Catholic Church did not remain a passive bystander that only reacted to the modernisation of socicty. In the second half of the ninetecnth century the Church went through a radical modernisation process that oddly enough, can be described in exactly the same terms as the transformation from traditional states into nation states. Ernest Gellner has, in a still influential book, described that process of transformation. His argument is that in an agrarian socicty state and culture do not overlap. Pre-industrial states consist of a large number of quite separate, local, oral low cultures, that are loosely held together by a small elite of soldiers and clerks (in a later book he speaks of the Red and the Black). ${ }^{18}$ That small elite is the only part of the population that participates in a higher supralocal written culture. So, in agrarian states many different cultures on many different levels can quite happily exist together within one state without causing any problem. ${ }^{19}$

But industrial society requires rationality and uniformity. Industry cannot properly function in a society that is governed by hundreds

16 Claude Langlois, 'Catholiqucs et laïcs', in Picrre Nora, ed., Les lieux de mémoire, III: Les France, 1: Conflits et parlages (Paris, 1992), pp. 140-83.

${ }^{17}$ E. Weber, Action française: Royalism and Reaction in Tiventieth-Century France (Stanford, 1962), pp. 34-35.

${ }_{18}$ Gellner, Nationalism (see above, n. 7), pp. 15-16.

${ }^{19}$ E.A. Gellner, Nations and Nationalism (Oxford, 1983), pp. 9-14. 
of different customs and traditions, it needs a society with a rationalised bureaucracy, where in the same situation the same rules apply to evcryone everywhere. Industrial society also needs large reservoirs of people who are able communicate with each other. Formal education, therefore, can no longer be confined to a small elite; it becomes a basic necessity for cveryone. The wholc population must be mobilised to keep industry going. But it is not enough that cveryone gets educated, everyone must be educated the same way, because only when people share the same outlook and the same culture they will be able to form the lines of communication that an advanced society requires. ${ }^{20}$ So what happened in the course of the nineteenth century was that in most states the written culture of the elite was imposed on the whole of the population, to create the larger cultural units that could sustain industrialisation. Local cultures were quite deliberately destroyed, and people were forced to becomc part of a much larger and much more homogeneous cultural network that became known as the 'Nation', in which state and culture now coincided. Nationalism, in Gellncr's view, is the idcology designed to soften that transformation and to make it bcarable. The new-fangled nations were presented as the natural and universal organising principle of all historical development. Historians rewrote Europe's history as the history of nations that had their origin in the Germanic and Slavic invasions of the carly Middle $\Lambda$ ges and, since then, had either developed gloriously and continuously (France and England), or had been suppressed and lain dormant for centurics to be awakened now (Germany, Italy and most of Slavic nationalisms). ${ }^{21}$

My point is that the Catholic Church in the nineteenth century went through a process of bureaucratisation, mass mobilisation and cultural homogenisation that was very similar to the formation of nation states. Up till the middle of the nineteenth century the Catholic Church can best be described as a loose federation of local churches, presided over by the Popc. At the top there always had becn a certain unity of doctrine and discipline, although the power of the local churches, in the first place the Ecclesia Gallicana, should not be underestimated. Underneath there was a confusing variety of customs and traditions that could differ from region to region and village to village. But after 1850 the Church changed into a tight bureaucratic

20 Ibid., 19-38.

21 Ibid., 40-50. 
organisation with a common homogeneous culture that was designed to embrace the life of ordinary Catholics everywhere in all its aspects, political, social, cultural and religious. The Church also developed its own national ideology, ultramontanism, thus called because the centre of the Church state was 'beyond the mountains', in Rome. Just like any other national state the Church developed its own national standard (yellow-white), its national anthem, and its orders of knighthood to reward deserving Catholics for their services to the Church. What the Catholic Church after $1850 \mathrm{did}$, was to try and create an alternative to the national state, or perhaps more preciscly, to change the Church into a national state which surpassed all other states, because of its divine origin and its universal destination, to gather all peoples of the world into one Catholic nation. The visiblc unity of the Church, supremely realised in its uniform liturgy, was the expression of the "nationalite unique en Occident", as it was aptly put by the Benedictine monk Prosper Guéranger. ${ }^{22}$ Thus in an age of nationalism the Catholic church by presenting itself as the supreme nation state, tried to impress upon its faithful that their first loyalty was still to God and the Church, and only after that to the nation state they inhabited.

This far-reaching modernisation of the Church was justified in the same way as in the new national states, with an appeal to history. Fundamental renewal was presented as a restoration of the medieval Church. The Middle Ages had been in fashion since the beginning of the nineteenth century. Romantic authors, such as Novalis, Schlcgel, de Maistre and Chateaubriand, had brilliantly argued that the chaos and confusion of the French Revolution could only be overcome, if Europe returned to the one true faith and on the basis of that faith established a community of nations under the leadership of the Pope, as it had been in the Middle Ages, when all princes had accepted the arbitrational powers of the Holy See. That romantic nostalgia for a (largely imaginary) medieval past, in which the Pope had allegedly been the supreme guardian of justice and peace, became the foundation of ultramontane ideology. ${ }^{23}$ Oddly enough, initially such romantic reverics about the role of the Pope in society met

22 Peter Raedts, 'Prosper Guéranger O.S.B. (1805-1875) and the Struggle for Liturgical Unity', in Continuity and Change in Christian Worship, ed. R.N. Swanson [Studies in Church History 35] (Woodbridge, 1999), p. 342.

${ }^{23}$ Rémond, Religion and Society (see above, n. 3), pp. 92-96. 
with considerable opposition in Rome itself. The Roman Curia did not want any renewal but a complete restoration of the relation between throne and altar, as it had existed before $1789 .{ }^{24}$ And when negotiating with princes it was unwise to emphasise the power of the Pope too much.

\section{Administrative centralisation}

The events of 1848 changed all that. Just like all other European courts the Roman Curia was deeply shocked by the destructive revolutionary spirit that came to the surface once more in that year. The Pope himself had to flec from Rome in disguise to escape from the fury of the crowds. In the aftermath of that revolutionary year the Roman authorities began to listen to what the romanticists had said fifty years before, that there could be no peace, harmony and unity in the world without a restoration of the all-embracing powers of the medieval Roman Pontiffs. From 1850 it became the conscious strategy of the Roman authorities to concentrate all power in the Church in Rome. Ancient privileges, if thcy had survived the French Revolution, were revoked. For the first time in history it became official policy in Rome to concentrate the appointment of bishops in the hands of the Pope. ${ }^{25}$ In their own dioceses the bishops, too, monopolised all appointments. Ancient rights of patronage were abolished, where they still existed (Germany, Austria-Hungary). More horizontal and collegial administrative bodies, such as national synods and chapters, that had survived from earlier days and had always acted as a check on papal or episcopal authority, were abolished or their power was severely curtailed. Fven informal meetings between bishops were discouraged or forbidden, their only contacts should be with their pricsts on the one hand and the Holy Sec on the other. ${ }^{26}$ It was ominous that the administrative model that the

${ }^{24}$ A. van de Sande, La Curie romaine au début de la restauration; le problème de la continuité dans la politique de restauration du Saint-Siège en Italie, 1814-1817 ('s-Gravenhage, 1979), p. 190.

25 It took considerable time to implement that policy. E.g. it was not until after the death of Franco in 1975 that Spain gave up the privilege of appointing its own bishops.

${ }_{26}$ For one example among many sec Klaus Schatz, Zwischen Säkularisation und zweitem Vatikanum. Der Weg des deulschen Katholizismus im 19. und 20. Jahrhundert (Frankfurt a.M., 1986), pp. 105-106. 
Congregation for the Propagation of the Faith had originally developed for missionary countries increasingly became the norm for all the Church; it meant more power for the Roman Curia without any new form of accountability. How scrious the consequences were is obvious when for one moment we try to imagine a situation in which the Indian Civil Service would have become the model for administrative reform in Britain. In such a systcm the whole hierarchy became nothing more than the exccutive arm of the Papacy, a perfect, rational top down bureaucracy that had no other duty than following orders from above. The French ultramontane priest abbé Combalot remembered the day of the proclamation of the dogma of the Immaculate Conception on December 8th 1854 and noted: "All eyes were focussed on the Pope, the bishops counted for nothing, they were like altar boys". ${ }^{27}$ That about describes it.

Another example of Roman centralisation policy was the change in education of the clergy. Since the sixteenth century there had been seminaries in Rome to educate pricsts for Protestant countries that had no seminaries of their own. The oldest and most famous was the Collegium Germanicum, founded by the Jesuits in 1552 for the North German mission. Others were the English and Irish Colleges. In the second half of the nineteenth century the function of these seminaries suddenly changed. The Roman Curia began to put a lot of pressure on all national hicrarchies, even in Catholic countries, to found national seminaries in Rome and to send their brightest scminarians, destined for higher things, there to be educated at the Papal universities. It was a perfect way of crcating a new supranational ecclesiastical clite, deeply attached to the Roman See and imbued with Romanita, the virtue to see all problems through the eyes of the Curia. In 1846 the Belgian bishops opened a seminary in Rome, followed by the South American countries in 1858, the United States in 1859, and Spain in 1892. By the end of the ccntury it became virtually impossible to get any advancement in the Church without an education in one of the Roman colleges. ${ }^{28}$

${ }^{27}$ A. Gough, Paris and Rome: The Gallican Church and the Ultramontane Campaign 18481853 (Oxford, 1986), p. 221.

${ }_{28}$ Peter Raedts, 'Tussen Rome en Den Haag: de integratie van de Nederlandse katholieken in kerk en staat', in De eenheid en de delen. Zuilvorming, ondenerijs en natievorming in Nederland 1850-1900, eds. Henk tc Velde and Hans Verhage (Amsterdam, 1996), pp. 36-37. 
Centralisation was accompanied and made palatable by new ceremonies and rituals. Never before had the person of the Pope been an object of devotion. It is quite likely that most Catholics in the eighteenth century did not even know the name of the reigning Pontiff. Pope Pius IX (1846-78) was the first Pope, whose portrait decorated the walls of Catholic homes and whose image was preserved in prayer books. ${ }^{29}$ His reputation among Catholics soared even higher when the Italian army occupied Rome in 1870 and the Pope 'imprisoned' himself in the Vatican. It was as if he bore the Cross of Christ. The bishop of Geneva spoke of the three Incarnations of Christ: in the womb of the Virgin, in the Eucharist and in the old man in the Vatican. ${ }^{31}$ Large pilgrimages to Rome becamc normal once the new railroad network had made the journey short and cheap. To see the Pope in Rome became a dream for which many poor Catholics saved for a lifetime. Papal court ceremonial, that had always been executed in the privacy of the Vatican or the Quirinal and to which only the happy few, such as Goethe, ${ }^{3 !}$ had been admitted, was now moved to St. Peter's Square or other public places, where large crowds could attend. ${ }^{32}$ Personal events in the life of the Pope such as his birthday or a jubilee, became public occasions. When Pope Pius IX celebrated his golden jubilee as a priest on April 11 th 1869, the Dutch poet-priest Schacpman called it a turning point in the history of humankind.

At the same time ordinary Catholics were mobilised with all the means that the modern mass media put at the disposal of the Church. Strategies were devised to turn all baptised Catholics into practising members of the Church. ${ }^{33}$ Responsible and worried Church leaders

29 M.N. Ebertz, 'Herrschaft in der Kirchc; Hierarchie, 'Tradition und Charisma im 19. Jahrhundert', in Zur Soziologie des Katholizismus, eds. K. Gabriel and F.X. Kaufmann (Mainz, 1980), p. 109: "Ausseralltäglichkeit... und dic erstmalige massenhafte Verbreitung des Papstbildes als kleines Andachtsbild cin altes und bewährtes Propagandamittel der Jesuiten - steigern die Verehrung des Papstes zur Christifikation".

${ }^{30} \mathrm{R}$. Aubert, Le pontificat de Pie IX [Histoire de l'Église depuis les origines jusqu'à nos jours 21] (Tournai, s.a.), p. 303.

31 See his - rather hilarious description of his attendance at the Pope's private Mass in the Quirinal on All Souls' Day, 2 November 1786, in J.W. von Goethe, Italienische Reise. Hamburger Ausgabe, ed. H. von Einem (München, 1992), p. 127.

${ }^{32}$ Klaus Schatz, Vaticanum I 1869-1870 [Konziliengeschichte, Reihe A: Darstellungen], 3 vols. (Paderborn, 1992), 1: 22.

3. Ebertz, 'Herrschaft in der Kirche' (see above, n. 29), pp. 103-108, calls it "Organisierung der Massenreligiosität". 
considered, what they now began to call the 'apostasy of the working classes', as one of the greatest dramas of the century. Now it certainly was true that the influcnce of the Church in the lower ranges of society had always been small. But it was not until the second half of the nineteenth ccntury that it was made into a problem that had to be solved. It was presented as a decline from the high medieval standards, although the reality probably was that the proletariat had never had morc than a nominal connection with the Church and the Christian faith. What was new was that the Church no longer resigned itsclf to the impossibility of reaching out to the lowest and poorest, but became conscious of the situation and tried to devise schemes to preach the Gospel to people in which it had never been much interested before.

Far morc important was that the Catholic Church was very quick to realisc that the spread of education to all segments of the population, so characteristic of the nineteenth-century modernisation, offered many new possibilities of bringing people into contact with the faith. Wherever possible the Church tried to get control of the public school system. Where that was not possible or no longer possible, as in France after 1870, a Catholic school system was set up with an astonishing speed. In all parts of Europe and America bishops and parish pricsts founded new religious congregations, mainly of women, with the express purpose of securing good and cheap education for as many Catholics as possible. The number of new foundations went into the thousands by the end of the century. And the old orders, too, both of monks and friars, more and more turned themselves into teaching organisations to meet the insatiable demand for Catholic education. ${ }^{3+}$ And once young Catholics had left school, an evergrowing Catholic press, in a rich variety of newspapers, illustrated magazines and devotional booklets, followed them in the home and the workplace to remind them of their sacred duties and commitments.

The main reason that the mobilisation strategy proved so successful was that at the same time as the Church tried to reach out to all Catholics, it also created a new and homogeneous Catholic

${ }^{34}$ Although all these foundations claimed to have their own purpose and spirituality, they were, in fact, remarkably similar, because, with the exception of the strictly contemplative orders such as the Trappists, they all ended up doing cxactly the same work: the spread of the new Catholic culture through education, missions and publishing. See the highly original work of $\mathrm{R}$. Hostie, Vie et mort des ordres religieux. Approches psychosociologiques ([Paris], 1972), pp. 236-51, 264-73. 
culture that proved extremely popular. I start from the top. From quite early on in the century Rome put an end to all theological diversity. German theologians, such as Günther and Hermes, who tried to reconcile idealist philosophy with Catholic doctrine were called to order, the writings of the convert John Henry Newman, perhaps the most original Catholic mind of the century, were simply ignored. Rome promoted the revival of medieval scholastic theology instead. In 1879 Pope Lco XIII went even further and in the encyclical Aeterni Patris proclaimed that all Catholic theology had to be founded on the writings of St. Thomas Aquinas "inter scholasticos doctores omnium princeps et magister". From then on even the study of such medieval luminaries as Scotus or Bonaventure was discouraged or forbidden..$^{3.5}$ This undoubtedly had the effect of turning the Catholic clergy into a hermetically sealed body of elect who communicated in an arcane language and reference system that even to ordinary Catholics was incomprchensible, let alone to the rest of the world.

In the liturgy, too, the Roman authorities pursued the ideal of complete uniformity and with success. In 1840 most dioceses of France still had their own liturgy and were proud of it. In the next forty years the Roman liturgy was introduced in all French dioceses, the last diocese that gave up its own traditions was Orléans in 1875. ${ }^{36}$ The same happened in Germany. Once the liturgy had been reformed, it was the turn of sacred music. Orchestras were banned from churches, mixed choirs that performed modern church music (Rossini, Gounod, Verdi) were disbanded and replaced by all male choirs that specialised in the restored medieval Gregorian chant or in sixteenth-century Roman polyphony (Palestrina, Lotti) It is fair to say that, despite considerable pressure from Rome, the musical reform was much less of a success than the liturgical. In Germany and Austria most churches held on to their mixed choirs and orchestras and rarely turned from Mozart, Haydn or Schubert to plainchant. For the first time the participation of the faithful in the liturgy was actively encouraged. Translations of the Roman missal became very popular, parishes organised liturgical wceks to explain the Mass to the faithful, and instead of silently watching the pricst perform his

35 Thomas F. O'Meara, Church and Culture: German Calholic Theology 1860-1914 (Notre Dame, 1991), pp. 28-29, 33-35; Otto Weiss, Der Modernismus in Deutschland (Regensburg, 1995), pp. 48-56.

${ }^{36}$ Gough, Paris and Rome (see above, n. 27), pp. 119-30, 168-80. 
rituals attendants at Mass were encouraged to say out loud the responses.

All these efforts to promote the official liturgy were only partially successful. Liturgical uniformity ccrtainly instilled a strong feeling in Catholics that all over the world they were one nation, praying to God in one language. But the official liturgical ritual was too remote from ordinary life and too chilly to appeal to ordinary people and turn them into morc cnthusiastic and committcd Christians. Ultramontane Catholics wcre acutcly aware of the fact that, if they wanted to mobilise the Catholic pcople, more popular forms of worship were necded, that went straight to the heart. They had to fight for that, because in the carly nincteenth century most pricsts still clung to the tenets of seventecnth-century Jansenism and cighteenth-century Enlightencd Catholicism. They condemned most forms of popular devotion as magic, loathed pilgrimages, processions, relics and wecping statues of the Virgin, they distrusted monks and their ascetic practices and they preached a stern, responsible and strongly cthical faith without smells end bells. In their view Christ had never spoken a truer word than when He had said: Many are called, but few are chosen. They were so convinced of the decp sinfulness of humankind that they activcly discouraged their faithful from going to Holy Communion, unless when absolutely necessary. ${ }^{37}$

When in the 1840 s the first ultramontane generation of priests became active, they saw it as their first priority to combat such elitism that, in their opinion, had alicnated ordinary people from the Church for centuries now. Instead they wanted to bring the people into contact once more with the extravagant devotions and mystical riches of the Middle Agcs that the Jansenist clergy had wanted to eradicate. In 1844 the bishop of Trier decided to put Christ's robe (Heiliger Rock), prescrved in the cathedral treasury, on display. Most educated German Catholics, laity and priests, were horrified at the spectacle and some accused the bishop of wilful fraud. But it was an immense popular success, more than a million Catholics travelled to remote Tricr to venerate the relic. ${ }^{38}$ In fact, the display of the

${ }^{37}$ Jacques Gadille and Jean-Marie Mayeur, cds., Histoire du christianisme des origines à nos jours, 14 vols. ([Paris], 1990-2001), 11: Libéralisme, industrialisation, expansion européenne, 123-27.

W. Detzler, 'Protest and Schism in Nineteenth-Century German Catholicism: The Rongc-Cizerski Movement', in Schism, Heresy and religious Prolest, ed. D. Baker [Studies in Church History 9] (Cambridge, 1972), pp. 341-42. 
Robe proved a decisive turn in the history of German Catholicism, for the first time German Catholics rallied proudly round their bishops expressing their unity in the face of a nation that thought Catholicism was un-German. It was also the first time that the ultramontane strategy to create or restore more popular and warmer forms devotion proved its worth. Apparently it was possible to reach out to ordinary Catholics, but then the barriers had to be: lowered and forms of worship that to an earlier generation had seemed superstitious or magical, or both, had to be revived and promoted.

But whilc pretending merely to revive medieval devotions ultramontane Catholics considerably changed them in content and scope. Veneration of saints who were of no more than local significance was discouraged or terminated. The reformers only promoted devotions that could have an appeal to all Catholics. The threc most important were the devotion to the Blessed Sacrament, to the Sacred Heart, and above all, to the Virgin Mary. More than any of the other two, Marian devotion became the hallmark of nineteenthcentury Catholic piety. ${ }^{34}$ In 1854 Pope Pius IX set the seal of official approval on this development with the solemn proclamation of the dogma of Mary's Immaculate Conception, an cvent that was symbolic both of the centralisation of power (never before had a Pope proclaimed a dogma outside a Council of the Church) and of the change of tone in Catholic worship.

\section{Pilgrimage}

The many apparitions of the Virgin at the same time led to the revival of yet another custom that had been frowned upon by an earlier generation, pilgrimage. Marian pilgrimage perfectly fitted into the ultramontane strategy to substitute new universalised devotions for traditional localised religious practices. ${ }^{+0}$ 'Turner has argucd that pilgrimage temporarily frees people from their everyday role in local society and by throwing them back on their individuality during the journey opens them up for the inclusive and universal values proclaimed by the sanctuaries thcy are travelling to. Although this the-

${ }^{39}$ Gćrard Cholvy and Yves-Maric Hilaire, Histoire religieuse de la France contemporaine, 3 vols., 2nd ed. ('Toulouse, 1990), 1: 1800-1880, 169-85.

4) Gadille and Maycur, eds., Histoire du christianisme (sec above, n. 37), 129; Cholvy and Hilaire, Histuire religieuse (see above, n. 39), 191-96. 
ory has come under scrutiny, ${ }^{41}$ for my purpose it explains perfectly why the Catholic authorities so actively began to foster pilgrimage to Marian sanctuaries from the 1850 s on. Ancient sites of pilgrimage, such as Rocamadour, Loreto and Altötting, which had fallen on bad times in the age of Enlightenment, were revived. But far more important were the new sites where Mary put in an appearance: La Salette (1846), Pompei (1875), Knock (1882), Fatima (1917), and the most successful of all, Lourdes (1858).

In 1858 the young shepherdess Bernadette had several apparitions of a 'lady' in a grotto near the river Gave. When Bernadette asked who the lady was, she revealed herself to be the Immaculate Conception. 'To the local clergy that was a sign of Bernadette's authenticity, for how could an illiterate girl know about the dogma that had been proclaimed four years before: it must have been a revelation. ${ }^{42}$ From then on success came quickly. In 1867 Lourdes was linked to the railway network, and the pilgrims began to flock to the miraculous grotto, first in their thousands, later in the millions each ycar.

Lourdes is the perfect example of the way in which the Church in the second half of the nineteenth century mobilised its faithful and tried to shape them into one universal, homogeneous Catholic body, under tight direction of a centralised and bureaucratised Papacy. Although Bernadette herself never so much as mentioned the Pope when reporting about her visions, the Bishop of Tarbes, and later the Roman authorities, were not slow in recognising that the events in Lourdes, if handled the right way, could constitute a powerful supernatural confirmation of the new role of the Papacy. Mary, by calling herself, according to Bernadette, the Immaculate Conception, four years after the dogma had been proclaimed, implicitly confirmed that the authority of the Pope in the Church was unique and rankcd high above that of the bishops, that it was, in fact, infallible. ${ }^{43}$

At the same time the elaborate rituals, processions and chants used during the pilgrimage in Lourdes became a common memory to Catholics all over the world, and thus created a shared identity that proved very strong. No one who participated could cver forget the candle processions at night or the blessing of the sick at the

${ }^{+1}$ Eade and Sallnow, eds., Contesting the Sacred (sce above, n. 2), pp. 4-5.

42 Harris, Lourdes (sec above, n. 2), pp. 32, 97-98, and 186.

+3 Eadc and Sallnow, eds., Contesting the Sacred (see above, n. 2), p. 32. 
grotto by day." All pilgrims brought home water (preferably in bottles shaped in the form of the Virgin) from the miraculous source that Bcrnadette had dug near the grotto. Its healing forces made pilgrimages to local sanctuaries superfluous. Ciopies of the grotto, in which Mary had appeared, were erected everywhere in the Catholic world, and often replaced local sanctuaries. In a small village near Redon in France the age-old pilgrimage to the chapels of St. Marcellinus (against fever) and St. Lawrence (against burnings) ceased suddenly once the Lourdes grotto had been built. The ancient sanctuary at Mont-Dol that had always been dedicated to St. Michael, and to a pagan god before that, was now crowned with a life size statue of the Virgin. ${ }^{1.5}$ French priests in those years liked to speak of this constant copying of the same religious symbols as "industries de zele" ," ${ }^{+6}$ a happy phrase that expresses the cssential modernity of the religious mobilisation that took the Catholic world in its grip between 1850 and 1900 .

\section{Conclusion}

As I said in the beginning, the history of the Roman Catholic Church since 1800, has usually been described, not in the least by Catholics themselves, in terms of crisis and decay, as if, in a rapidly changing world, the Church was a venerable relic of days gone by. What I tried to argue was that another description fits the facts far better. It is possible to describc the transformation of the Catholic Church in the same terms as the transformation of states into nations: rationalisation and centralisation of the administration, mobilisation of all the people, and the creation of a low-brow, homogeneous, common culture.

An objection could be that this modernisation was all about form, but not about content. Was not ultramontanism the complete denial of modern industrial society and of everything the French Revolution stood for? That is true, but in that, too, the Catholic Church was

\footnotetext{
${ }^{44}$ For a description of the pilgrimages and the 'miraculous' healings see Harris, Lourdes (see above, n. 2), pp. 258-331.

t5 M. Lagrée, 'Religion populaire et populisme religieux au XIX' siècle', in: Histoire vécue du peuple chrétien, ed. J. Delumeau, 2 vols. ('Toulouse, 1979), 2: 169.

${ }^{t h}$ H. Jcdin, ed., Handbuch der Kirchengeschichte, 7 vols., 2nd ed. (Freiburg i.B., 1985), VI.1: Die Kirche zioischen Revolution und Restauration, p. 439.
} 
no exception. Most new nation states tried to soften the brutal impact of the process of modernisation by presenting it as a restoration of times gone by or by suggesting continuity where, in fact, there was none. Historians have called this the 'Invention of Tradition'. ${ }^{77}$ And most nations defince their individual character by contrasting it with revolutionary France. In Germany it became commonplace to compare the profundity of German Kultur, founded in the medieval empire, restored in the nineteenth century, with the superficial and unhistorical Zivilisation of the West, where the only things that counted were ruthless competition, egalitarian democracy and rampant individualism. The English liked to contrast their own continuous history of growing freedom and prosperity with the unhappy revolutionary convulsions on the continent of Europe.

Iikcwise the Catholic Church presented itself as the weak and lone guardian of the sacred in a world of rampant secularism and paganism. As never before the Church emphasised those elements in doctrine and ritual that distinguished it from the surrounding world and from the Zeitgeist. Clerical attire was never more deliberately differcnt from normal fashion than in the nineteenth century. Miracles, relics, apparitions, medicval logic, they were nothing to be embarrassed about, but in their stark contrast to everything modern, in their apparent weakness and folly, they uniquely visualised the sacred and the supcrnatural. And nowhere that cherished absurdity was more kecnly perceived that in the position of the Pope. Ultramontane Catholics, as we have seen, turned the Pope almost into a living God on earth. In theory he was not only the infallible head of the Catholic Church, but he was also the king of kings, the natural leader of the world to whom all princes should turn for counscl. In fact, the Pope was the inhabitant of a minor, decayed capital in a corrupt, backward country and, after 1870, a prisoner in his own palace. It was that complete contrast between theory and fact that the ultramontanists confirmed in their faith that 'the foolishness of God is wiser than men, and the weakness of God is stronger

${ }^{47}$ F. Hobstbawm and T. Ranger, eds., The Invention of Tradition (Cambridge 1983), p. 2, define 'invented traditions' as "responses to novel situations which take the form of reference to old situations, or which establish their own past by quasi-obligatory repetition. It is the contrast between the constant change and innovation of the modern world and the attempt to structure at least some parts of social life within it as unchanging and invariant, that makes the 'invention of tradition' so interesting for historians of the past two centuries". 
than men'(1 Cor. 1,25). The Church's weakness was the best proof of God's triumph. And to make sure of that triumph Catholics liked to tell their story as one of persecution, suffering, and defeat. But I hope to have shown that as a diagnosis of what happened to the Catholic Church in the nincteenth and the first half of the twentieth centuries it is completely misleading.

Macaulcy, who saw things from the height of enlightencd unbelief, had no doubts whatsoever about the surviving powers of the Roman Catholic Church. As carly as 1840 he wrote in a review of Ranke's history of the Papacy:

The papacy remains, not in decay, not a mere antique, but full of life and youthful vigour... [and then of the Church] Nor do we see any sign which indicates that the term of her long dominion is approaching. She saw the commencement of all the governments and of all the ecclesiastical establishments that now cxist in the world; and we feel no assurance that she is not destined to see the end of them all. She was great and respected before the Saxon had set foot on Britain, before the Frank had passed the Rhine, when Grecian eloquence still flourished in Antioch, when idols were still worshipped in the temple of Mecca. And she may still exist in undiminished vigour when some traveller from New Zealand shall, in the midst of a vast solitude, take his stand on a broken arch of London Bridge to sketch the ruins of St Paul's. ${ }^{18}$

+8 Thomas Babington Macauley, Critical and Historical Fssays, 2nd ed. (London, 1874), p. 548 . 